Original research article

\title{
Typology of informal carers providing care to family members after cerebrovascular accident
}

\author{
Miroslav Paulíček ${ }^{1}$, Lenka Krhutová ${ }^{1}{ }^{*}$, Iva Kuzníková ${ }^{1}$, Kamila Vondroušová ${ }^{1}$, Iva Tichá ${ }^{1}$, \\ Hana Lukšová ${ }^{1}$, Petra Anna-Marie Blahová ${ }^{1}$, Veronika Valoušková ${ }^{1}$, Marcela Dabrowská ${ }^{2}$, \\ Jarmila Kristiníková ${ }^{2}$, Petr Šaloun ${ }^{3}$ \\ ${ }^{1}$ University of Ostrava, Faculty of Social Studies, Department of Health and Social Studies, Ostrava, Czech Republic \\ ${ }^{2}$ University of Ostrava, Faculty of Medicine, Department of Rehabilitation, Ostrava, Czech Republic \\ ${ }^{3}$ VSB - Technical University of Ostrava, Faculty of Electrical, Engineering and Computer Science, Department of Computer Science, Ostrava, \\ Czech Republic
}

\section{Abstract}

Introduction: The study is underpinned by the research of people providing care to relatives after a cerebrovascular accident outside the sphere of public institutions - so called informal carers. The aim was to create a typology of these carers, reflecting their way of constructing identity, their attitude to their own emotions, their reflections on and experience with caring, their forms of communication, and how they work with information.

Methods: The research was led by a qualitative approach with the use of the principles of biographical research. It is based on thirty semistructured interviews. Areas were identified within these interviews in which the carers reflected on themselves. Through these areas, the carers differ in the ways in which they experience their roles of carers. The research was complemented with a questionnaire survey in order to acquire demographic and other data from the same sample.

Results: The result of the study is a typology which contains five pure types of informal carers who provide care to family members after a Cerebrovascular Accident (CVA): (1) rational, (2) self-construing, (3) depressive, (4) traditional and (5) optimistic.

Discussion: The results of the study are discussed in the context of caregiving in general, and in comparison with research focusing on the ways in which carers cope with decreased autonomy, emotions, gender, or their approach to obtaining information.

Conclusions: Within the above types, carers differed in the variety of ways in which they controlled their emotions, in the different relationships to self, or in their reflections on the future. Which category an individual carer fell into depended on the volume of care they provided, how long they had been providing it, the possibilities to obtain support or assistance, and the personality of the carer. This typology may be useful from the analytical perspective, as well as from the perspective of potential interventions aimed at the dissemination of information and the sharing of the carers' experience.
\end{abstract}

Keywords: Cerebrovascular accident; Informal carer; Typology

\section{Introduction}

For a long time, both professionals and lay people showed little interest in informal carers. The change in the attitude to informal carers which we have been witnessing over the last decades is primarily - although not exclusively - caused by the urgent need for a solution to the demographic trends of population ageing. In parallel with the situation in other countries, informal carers in the Czech Republic have neither been sufficiently identified, nor systematically supported. "While it is possible to define other focus groups by a certain social event (such as maternity by giving birth) or socio-economic characteristics (such as age in senior citizens or lack of employment in the un- employed), caregivers are a group that is largely non-demarcated/ undefined." (Geissler, 2021: 56)

This is reflected also in the area of terminological definition of informal care and informal carers. This area is highly divergent and differs in the depth and the breadth of the definition concepts, the purposes of the definitions, the definition criteria chosen, as well as the fields in which (or for which) the terminology is defined. For the purposes of this paper, we will proceed from the similarities found in these definitions. In the absence of terminological consensus (if it can ever be achieved), terminological definitions of informal care - and hence of informal carers - usually have the following in common: “... informal care involves lay [...] care conducted without any specific professional education, without financial remuneration

\footnotetext{
* Corresponding author: Lenka Krhutová, University of Ostrava, Faculty of Social Studies, Department of Health and Social Studies, Českobratrská 16, 70103 Ostrava, Czech Republic; e-mail: lenka.krhutova@osu.cz http://doi.org/10.32725/kont.2021.039
} 
and outside of one's employment, and is accompanied with a high degree of emotional involvement." (Horová et al., 2021: 23)

Concurrently, lay care may include the involvement of both family members as well as friends, neighbours, acquaintances or colleagues and the like.

One of the key factors with regard to support provided to informal carers is how well informed these carers are. This information process is often marred by obstacles (Geissler et al., $2015 a, b)$ as carers are exposed to the deficits of an "invisible group", and it is not infrequent that information reaches them in a haphazard manner. These people are not always aware of the fact that, as a result of their caregiving, they themselves may belong to a group of people whose physical, psychological, social or economic, etc., health may be at risk. For a number of reasons, unlike care recipients themselves (i.e., people who suffered CVA in our case, or children with a disability and the like), informal carers do not set up formalised associations. With the exception of a type of sickness benefit recently introduced in the Czech Republic under the name "long-term care benefit", informal carers are usually not visible both for the formal systems of support and from the perspective of their potential to form self-help groups. Among other problems, this also significantly hinders research in this area, or as the case may be, identification and searching for potential research respondents.

Informal carers have become an ever-more frequent object of professional investigation (for instance Horová et al., 2021; Hubíková, 2021). Research in this area deals with the informal carers' contribution to the economy (Mosquera et al., 2015), or attempts to quantify how well informed carers are (Araújo et al., 2015; Morris and Thomas, 2002). It also focuses on the quality of their life (White et al., 2004), satisfaction (Simon et al., 2003), situation on the labour market (Casado-Marín et al., 2011), how effective intervention is in reducing their strain (Nemčíková et al., 2020), or with their emotions and stress (Pesantes et al., 2017). Research which is relevant in relation to the focus group of our research and of this paper also includes research focusing on informal carers in the context of caring for people after cerebrovascular accidents (Albrecht et al., 2015; Chen et al., 2017; Imarhiagbe et al., 2017; Joo et al., 2014; Pendergrass et al., 2015).

This study belongs to research focusing on the typology of carers. From the point of view of further research practice, a typology, i.e. the constructing of a set of individual types of carers according to specific characteristics, may be a useful analytical tool (Weber, 2012). When designing the study, it was partly possible to rely on the already existing typologies - for instance Jegermalm (2006) created a quantitative typology of informal carers in the Swedish context and construed the individual types based on what activities the carers provided (e.g. accompanying care recipients, looking after them, helping with the household, and the like). The German typology created recently (Neubert et al., 2020) reflects the ways in which care is divided among family members caring for people with dementia - the families' approaches form an imaginary scale running from "we stick together" to "there's no other possibility". However, these typologies do not take into account the carers' experiences and feelings and their self-reflection - which is the focus of other, qualitative research (e.g. Brémault-Phillips et al., 2016; Strang et al., 2019).

In our study, we proceed from our own data and the typology was created on the basis of those data - the typology reflects significant aspects of care, such as the informal carers' way of construing identity, their approach to their emotions, how they reflect on and experience provision of care, the forms of their communication or the ways of working with information. This study forms part of a broader project aiming at the experimental development of information systems for informal carers who take care of people after cerebrovascular accidents. Within the framework of that ongoing project (2019-2021 - see Acknowledgements), the results of this study are used for a more targeted support of dissemination of information, and for the sharing of experience and feelings of the carers who are involved in agile software development. The study was designed as a secondary analysis of data from the primary research conducted within this project.

The goal of creating the aforementioned typology directs us organically to the following research question: what approaches to care and what ways of experiencing its provision is it possible to identify in informal carers providing care to people after CVA?

\section{Materials and methods}

The research was led by a qualitative approach making use of the principles of biographical research (Fischer-Rosenthal and Rosenthal, 2001; Rosenthal, 2018) - particularly what concerns the capturing of the life dynamics and the overall development of communication partners within the context of significant life events. The study is based on thirty semi-structured interviews. Areas were identified within these interviews in which the carers reflected on themselves, and through which the ways in which they experienced their roles of carers differentiated them from one another. The research was complemented with a simple questionnaire survey in order to acquire demographic and other data from the same sample.

\section{The basic and selective set}

As already mentioned, this study was designed as a secondary analysis of data from the primary research performed within the experimental project of agile software development. The basic set of the primary research was formed by informal carers who take care of their loved ones after CVA in the Moravian-Silesian Region (in relation to the pilot research in this region). Selection of communication partners for the research was conducted in various ways. Selection was basically purpose specific; contacts to general practitioners and services providing support to people after CVA were used, as well as the researchers' personal contacts combined with the "snowball" technique. Advertisements were also published in the regional press and presentation media of municipalities, etc.

The individual interviews (transcripts of the interviews) with communication partners were used to create the corresponding data sets. Within the primary research of this project, the theoretical data sample saturation point occurred between the 25th-30th data set, so in comparison with research projects focusing on similar topics, the size of the research sample in our study is a standard one. (Barbic et al., 2014; Greenwood and Mackenzie, 2010; Smith et al., 2004).

\section{Research sample characteristics}

The interviews were conducted with thirty communication partners who were taking care of a loved one after CVA during the period of data collection (August 2019 - March 2020), and 56.7 per cent of these loved ones were women. In terms of the relationships between carers and the cared for, 12 carers (40 per cent) were spouses, i.e. husbands or wives. The same percentage of carers were children, i.e. sons or daughters. In two cases, the carer was a niece or nephew of the cared 
for, and in individual cases, they were the grandson/granddaughter, mother/father, brother/sister and cohabitee of the care recipient. The highest number of the interviewed - ten (34.5 per cent) - had been providing care for between five and ten years; three of them, i.e. 10.3 per cent, between three and six months, seven and twelve months or between one and two years; five of them (17.2 per cent) had been providing care for between two and five years; four of them (13.8 per cent) for more than ten years; and 22 of these carers (73.3 per cent) shared a household with the person close to them at the time of the CVA attack. Most of the interviewed - 17 of them, i.e. (56.7 per cent) - cared for their loved one after CVA at the place of his or her residence. The median length of care provision was thirty hours. With regard to the physical function of the recipients of care provided by the communication partners (as described by the carers themselves), the care recipients were at least partially mobile (70 per cent) and fully or mostly oriented (90 per cent). At the same time, 60 per cent needed help with getting dressed, 60 per cent had problems speaking, 40 per cent had problems understanding spoken language and 73 per cent had problems with memory. In relation to the physical strain that caregiving represented for the carers, five of them (16.7 per cent) described it as severe strain and one of them as absolute strain, nine (31 per cent) as medium, eleven (37.9 per cent) as mild, and three of them (10.3 per cent) described it as no strain at all.

Two (6.7 per cent) of the interviewed perceived the psychological strain to be absolute, the same percentage stated that they did not feel any psychological strain. The highest number, eleven of the interviewed (36.7 per cent) described psychological strain as severe, eight of them (26.7 per cent) as medium and seven (23.3 per cent) as mild. Four of the interviewed people (13.3 per cent) stated they felt total exhaustion and the same number described their exhaustion as severe. The highest proportion, nine of the interviewed (30 per cent), described their exhaustion as medium, seven of them (23.3 per cent) experienced mild exhaustion, and six of the interviewed (20 per cent) did not feel any exhaustion.

\section{The procedure}

The semi-structured interviews were primarily held with the aim of supporting the communication partner in his/her reflection on his/her caregiving situation, i.e. to make it possible for him or her to get beyond the needs of the care recipient, and to make the caregiver think about changes in his/her life, and help him/her articulate his/her needs and deliberate over the things which might help him/her fulfil these needs. The general structure of the interview was based on biographical interviews (Fischer-Rosenthal and Rosenthal, 2001; Rosenthal, 2018). We asked the communication partners questions focusing on how they perceived their life situation at certain times in their lives - in this case, before the CVA attack suffered by the loved one they cared for, at the early and later stages of caregiving, and at present. After the interview, we filled in a questionnaire with the communication partners in order to obtain basic data about the caregiver and care recipient. The interviews lasted between 20 and 80 minutes. (The total length of all audio recordings of the interviews was 18 hours, with a total time of 206 hours spent on their verbatim transcription for the subsequent analysis.)

\section{Analysis}

The transcribed interviews were manually analysed by the researchers themselves using open coding. On the basis of the categories developed, which among other themes were also concerned with the way in which the caregivers spoke about themselves, their emotions, their relationship with the loved one to whom they were providing care, about their needs, how well informed or knowledgeable they felt, or about the future, a typology of the carers was created of so-called ideal types which, according to Weber (2012), represent a mental image which is formed by the accentuation of selected qualities terms (phenomena) may be classified: "They may be broken down into complexes of characteristics; but, in that case, not only the boundary between the two concepts but also their substantive content will necessarily remain fluid." (Weber 2012: 127)

What Weber means by this changeability is that particular cases may, and in reality must, deviate and be different in various features from the so-called "pure" type (a mental construction based on empirical reality). The basis for the creation of the typology was the researchers' consensus on the basic qualities of the individual communication partners - for each of the interviews, each of the researchers formulated one-word characteristics of the communication partner, and those designations concerning which there was unequivocal agreement among the researchers, were afterwards specified more closely and filled with content using the categories obtained by open coding. The individual types were then described through the characteristic statements from the individual categories, based on the similarities and differences between the categories.

\section{Results}

A typology of five pure types of informal carers providing care to family members after CVA was created and this typology includes the following types: (1) rational, (2) self-construing, (3) depressive, (4) traditional and (5) optimistic. However, in reality, it is a combination of these types that can be found. The rational type has a matter-of-fact approach to his/her emotions and clearly understands that it is necessary to take care of a loved one, but also of himself/herself; the self-construing type lacks such reflection and construes his or her identity predominantly on the basis of the care recipient; the depressive type emphasises negative emotions and his/her attitude to self is sometimes almost destructive; the traditional type emphasises duty in his activity and legitimises the insufficient reflection by tradition; the optimistic type accentuates positive emotions and is characterised by keeping on top of things and by his/her orientation to the future. Table 1 offers a summary of the characteristics of the individual types. We also provide a more detailed description of these types through the authentic statements of the communication partners of the research.

\section{Rational type}

Although he/she may sometimes appear to be emotionally cold, the rational type of carer does not lack emotions, and he or she can also work with them and speak about them in a matter-of-fact manner. The statements of this type of communication partner frequently contain the control of emotions: "I sometimes do get upset, of course I do, too, and then I have to wait and cool off, and sometimes I feel sorry and sometimes I just brush it aside" (P2/34). These carers also apply this matter-offact approach to the care recipient, and likewise, they can rationally contemplate their future: "There's still some time before I can retire, some period of time, and when he's not here any more, what will I do when he's not here because I can hardly go back to work, or I can hardly find a job (...), like, you know, my future's so uncertain, so, like this. In fact my own personal, professional, as 
Table 1. Typology of informal carers providing care to persons after CVA

\begin{tabular}{|ll} 
Type & Characteristics \\
\hline Rational & $\begin{array}{l}\text { Has a matter-of-fact approach to own emotions } \\
\text { and clearly understands it is necessary to take care } \\
\text { of a loved one, but also of oneself; reflects upon } \\
\text { the future rationally; organizes his/her time and } \\
\text { relaxation; actively searches for information, has a } \\
\text { critical approach to information }\end{array}$ \\
\hline Self-construing & $\begin{array}{l}\text { Fails to understand that it is also necessary to } \\
\text { take care of oneself; creates his/her identity } \\
\text { predominantly on the basis of the care recipient }\end{array}$ \\
& $\begin{array}{l}\text { Emphasises negative emotions and his/her attitude } \\
\text { to self is sometimes almost destructive; accentuates } \\
\text { having to do all the work himself/herself and does } \\
\text { not expect help from others or even rejects such } \\
\text { help; the reasons for rejection oscillate between the } \\
\text { effort not to bother others and the fear of rejection, } \\
\text { at the same time, however, this type appreciates if } \\
\text { someone helps him/her }\end{array}$ \\
\hline Traditional & $\begin{array}{l}\text { Emphasises duty in his activity and legitimises the } \\
\text { insufficient reflection by tradition }\end{array}$ \\
\hline Optimistic & $\begin{array}{l}\text { Accentuates positive emotions and is characterised } \\
\text { by keeping on top of things and by his/her } \\
\text { orientation to the future }\end{array}$ \\
\hline
\end{tabular}

man, I don't know" (P7/56). This type of a carer is well aware of his/her needs, he organises his/her time and the time for relaxation and rest. $\mathrm{He} / \mathrm{she}$ knows that in order to take good care of another person, he/she has to take care of himself/ herself, too. $\mathrm{He} / \mathrm{she}$ meets with friends and also with other family members: "Don't deal with it 24/7, like, this is what helps, not to do it all the time, you need to relax, that's important. To spend some time away from him, not to be in touch with him all day long, that's the most important thing" (P2/88). At the same time, the rational type has a responsible approach to information - searching for it actively and approaching it with critical thinking. "Of course, I also tried to search for information on the Internet, ... but unfortunately on most..., today anyone can post anything on the Internet, whatever they want, whoever they are, and one has to decide if it's relevant or not" (P7/106).

\section{Self-construing type}

Unlike the other types, the self-construing type is unable to reflect on his/her own situation at all, or if so - only insufficiently - because these carers construe their identity purely on the basis of their caregiving or on the person to whom they provide care. The typical element in such carers is that even if asked questions about their own situation, problems or needs repeatedly and several times, they are not able to reflect on themselves, and they always start speaking about the needs of the care recipient. This type can be on the verge of a certain kind of self-destruction due to this lack of self-reflection. Q: "... what did you need as a carer? And mind you, I'm not asking about your husband, I'm asking about you!" A: "Sure, I get it, physical strength, that's what I was lacking, because since then I more or less have had to help him sit up when he's in bed, and then stand up, so that's all" (P26/501).

\section{Depressive type}

This type of carer often speaks about his/her physical and primarily psychological exhaustion (fatigue), and also mention it is impossible to find a way out of that condition: "And I couldn't sleep at night, either, because I worried" (P8/312). "My sleep was so, like, you know, I didn't know what to do, I did not get any advice from anyone" (P26/218). At the same time, the depressive type emphasises the fact that he/she has to do all the work himself/herself while they do not expect anyone to help them, or they even reject such help. The reasons behind this rejection vary. Most often they are due to the effort not to bother others, or to the fear of rejection: "I don't think anyone would help, I take care of his work, that's something nobody will help me with, and nobody else will help with this worry, either, so unfortunately, I have to handle it myself, I didn't have the feeling that perhaps even some acquaintances who offered help, that they could [...], so what is it they could help me with, they won't help me with anything" (P8/143). "I didn't know what I should do, I didn't get any advice from anyone at all, in this (...) like, they did not tell me to go somewhere either, to the hospital, to get advice, or ..., not at all, really, not at all” (P19/176). “... I don't know who would come and help me. You don't want to bother anyone all the time and call anyone, like for instance, to help me get him into the bathtub, so I have to cope with it myself" (P11/202).

Although these carers do not expect help or reject it ostentatiously, they are able to appreciate it if they receive some. For instance, one of the communication partners said the following words about a doctor who went out of her way to help the carer: "She's an amazing person, she's a young doctor but I can say that (...) I was like Alice in Wonderland, she called me at night to ask if my temperature fell, she was on vacation in Slovakia with her little children, so I was totally ..., I was crying, I couldn't speak" [crying] (P21/286).

\section{Traditional type}

The traditional type does not reflect on his/her position of a carer much because these carers consider it to be natural. They often mention their strong bond to their family or Christianity. In connection with this, it is particularly women who emphasise their ability to uphold the traditional role of those who take care of the whole family and household:

"... so I cook all the time, this is relaxation for me, maybe it will sound silly, but like, I try to give my all to the family on Saturday and Sunday, to give what I have no time for during the week when you always make dinners but you make those more simple meals, but on Saturday and Sunday, I make those classic meals which the family likes, the real consomme and so on, these are time tested things and I cooked them for my parents, too" (P17/317). "So in fact, I got fired, well, but like, even so I have his full time job as my work, and of course I have children at home, what with the cooking, a husband, the whole house, I have more than enough to do all day" (P17/382). This type also has a conservative approach to technologies, which may influence how they work with information and how well informed they are. They often reject computers. "I' $m$ not the one to sit at the computer and look up things, you know, for me, the priority is to stand up and, I don't know, go work in the garden and not to look up everything on the PC. It's nonsense, because these older people, like I'm not so old, but I grope in the dark, too and if it wasn't for my neighbour, I don't know, perhaps we look like two idiots, so I don't know..." (P13/298). “... but it always unnerves me when people say go find it on the website, on www, so I look at her and many times I say I don't have a computer" (P6/303).

\section{Optimistic type}

The optimistic type could be considered a special type of the rational type, but with a strong sense of humour and the tendency to emphasise their optimistic personal attitudes. These 
carers' orientation to the future and their ability to stay on top of things may conceal their insufficient interest in themselves. They sometimes like to emphasise their optimistic orientation: "I've set my life to optimism" (P14/122). "... these parents of mine, they've taken so much energy from me during these five years, and if I were pessimistic, and negative, I think I wouldn't be sitting here with you..." (P3/233). At the same time, these carers place emphasis on mental hygiene and rest. "When I felt blue, it was always about exercise ... the dog ... letting off steam in the gym, I have to go and get totally recharged ... I need it" (P29/458). "My work, that's where I recharge" (P14/364). "I recharge my energy from people" (P3/280).

\section{Discussion}

Caregiving in general is usually perceived in two more or less intertwined dimensions - in carers, it represents both identity (identification with the care recipient) and activity, both love and work - in the words of one communication partner, it is work "that never ends, it is "an endless sentence". It is particularly the theoretical distinction of whether care proceeds from emotions and ethical principles, or whether it is primarily a strenuous and exhausting work that has relatively significant consequences in practice, especially for the carer and the attention paid to his/her needs (Dudová, 2015). The self-construing and traditional types maintain that caregiving is ethically determined and natural, but this aspect is less present in the depressive type, while the rational and optimistic types attempt to balance these two aspects.

Greenwood et al. (2010) investigated how carers coped with the loss of their autonomy and the reduced control over their lives. The basic problems included unpredictability, lack of choices, feelings of helplessness, inability to plan, the care recipient's constant dependence on the carer, or paradoxical dynamics in which the increasing autonomy of the CVA survivor decreases the autonomy of the carers.

To avoid these undesirable phenomena, carers choose various strategies in their lives aimed at increasing their autonomy - such as optimisation of activities, giving up activities, substituting certain activities with others, obtaining help from others, or negotiating about paid care. These strategies more or less correspond with the rational type of carer, and the research revealed that decreased autonomy may be tackled using other techniques. For instance, the self-construing type accepts this reduced autonomy, and so does the traditional type of carer who legitimises this acceptance by tradition and duty. Other research (Jeřábek, 2013; Smith et al., 2004) also shows that as a result of the need to provide care, carers most frequently give up the time they have for themselves, their hobbies, and the time for relaxation and vacation.

According to another qualitative research of carers providing care to CVA survivors (Barbic et al., 2014), reduction of activities belongs to the five main dimensions which influence emotional vitality, the other dimensions being physical health (including fatigue and lack of sleep), emotional health (loneliness, anxiety, stress), coping with new skills and roles (for instance in household care) and the ability to seek help (from family, friends or the healthcare system). Understandably, all of these aspects have a certain influence on which types in our typology a carer comes close to. As was already mentioned, a typology of ideal types does not mean that the individual types cannot overlap, and likewise, the individual setting of a carer may also change, for instance with respect to the form of the dimensions of this emotional vitality, or due to the strenuousness of care, its length or the carers' health condition (Smith et al., 2004). There also exists research which compares male and female caregivers; according to its results, it is more frequent for men not to increase the volume of care above an endurable level and men are also better at separating the individual areas of their life (Dudová and Vohlídalová, 2018). On the basis of that they ought to more often belong to the rational type, which is in correspondence with our research. On the other hand, the presumption (ibid.) that men primarily focus on the provision of "sufficient care" while women focus on the provision of "the best care" did not really prove to be true.

Taking into consideration the goal of the primary research project (see Acknowledgments) to which the partial research presented in this study is linked, the way in which the individual types of carers approach information is of essential importance. If the purpose of this project lies in the utilisation of technologies to link carers and to increase their knowledge or improve their psychological condition, it is crucial to focus on the depressive and self-construing types because they have the highest tendency to overlook their needs, and at the same time, also on the traditional types because these carers - in the context of this study - are those who most often refuse to use information technologies.

\section{Conclusions}

On the basis of our research, it is possible to divide informal carers who provide care to persons after CVA into five ideal types - rational, self-construing, depressive, traditional/conservative and optimistic. Within these types, carers differed in the variety of ways in which they controlled their emotions, in the different relationships to self, or in their reflections on the future. Which category an individual carer fell into depended on the volume of care they provided, how long they had been providing it, the possibilities to obtain support or assistance, and the personality of the carer. The typology contains these pure types of carers providing care to persons after CVA, however, in reality, it is a combination of these types that can be found. This typology may be useful from the analytical perspective as well as from the perspective of potential support aimed at the dissemination of information and the sharing of the carers' experience.

\section{Conflict of interests}

The authors have no conflict of interests to declare.

\section{Acknowledgements}

This research was supported by the Technology Agency of the Czech Republic within the framework of the project "Research and development of support networks and information systems for informal carers for persons after stroke" - implemented by the University of Ostrava and VSB - Technical University of Ostrava, project ID: TACR/TL02000050, project duration: 2019-2021. We would also like to express our gratitude to the application guarantors of the project - The Association for Rehabilitation of People after Cerebrovascular Accidents and the Moravian-Silesian Region. 


\section{Typologie neformálních pečujících o blízké po cévní mozkové příhodě}

\section{Souhrn}

Úvod: Studie se opírá o výzkum osob pečujících o blízké po cévní mozkové př́ihodě mimo veřejné instituce - tzv. neformálních pečujících. Jejím cílem bylo vytvořit typologii pečujících, která odráží jejich způsob konstrukce identity, přístup k vlastním emocím, reflexi a prožívání péče, formy komunikace nebo způsoby práce s informacemi.

Metody: Výzkum byl veden kvalitativním přístupem s využitím principů biografického výzkumu. Studie vychází z třiceti polostrukturovaných rozhovorů. Jejich prostřednictvím byly identifikovány oblasti, v nichž pečující mluvili sami o sobě a jimiž se navzájem odlišují v proživání své role pečujícího. Výzkum byl doplněn o dotazníkové šetření k doplnění demografických a dalších dat na stejném vzorku.

Výsledky: Výsledkem studie je typologie, která obsahuje pět čistých typů neformálních pečujících o blízké po cévní mozkové příhodě: (1) racionální, (2) sebekonstruující, (3) depresivní, (4) tradiční a (5) optimistický typ.

Diskuse: Výsledky studie jsou diskutovány v kontextech péče obecně a v komparaci s výzkumy zabývajícími se tím, jak se neformální pečující vyrovnávají se sníženou autonomií, emocemi, genderem nebo jejich přístupem k informovanosti.

Závěr: V rámci uvedených typů se pečující vyznačují růzností ovládání svých emocí, rozmanitým vztahem k sobě nebo uvažováním o budoucnosti. Zařazení do typů závisí na velikosti zátěže pečujícího, době pečování, možnostech pomoci či osobnostním zaměření. Tato typologie může být užitečná jak analyticky, tak z hlediska potenciálních intervencí k podpoře informovanosti a sdílení zkušeností pečujících.

Klíčová slova: cévní mozková příhoda; neformální pečující; typologie

\section{References}

1. Albrecht D, Wollensak T, Ernst C, Becker C, Hautzinger M, Pfeiffer K (2015). Costs of informal care in a sample of German geriatric stroke survivors. Eur J Ageing 13(1): 49-61. DOI: 10.1007/s10433-015-0356-x.

2. Araújo O, Lage I, Cabrita J, Teixeira L (2015). Intervention in informal caregivers who take care of older people after a stroke (InCARE): study protocol for a randomised trial. J Adv Nurs 71(10): 2435-2443. DOI: 10.1111/jan.12697.

3. Barbic SP, Mayo NE, White CL, Bartlett SJ (2014). Emotional vitality in family caregivers: content validation of a theoretical framework. Qual Life Res 23(10): 2865-2872. DOI: 10.1007/s 11136-014-0718-4.

4. Brémault-Phillips S, Parmar J, Johnson M, Huhn A, Mann A, Tian V, Sacrey L-A (2016). The voices of family caregivers of seniors with chronic conditions: a window into their experience using a qualitative design. Springerplus 5: 620. DOI: 10.1186/ s40064-016-2244-z.

5. Casado-Marín D, García-Gómez P, López-Nicolás Á (2011). Informal care and labour force participation among middle-aged women in Spain. SERIEs 2: 1-29. DOI: 10.1007/s13209-0090008-5.

6. Chen P, Fyffe DC, Hreha K (2017). Informal caregivers' burden and stress in caring for stroke survivors with spatial neglect: an exploratory mixed-method study. Top Stroke Rehabil 24(1): 24-33. DOI: 10.1080/10749357.2016.1186373.

7. Dudová R (2015). Postarat se ve stáří. Rodina a zajištění péče o seniory. Praha: Sociologické nakladatelství (SLON).

8. Dudová R, Vohlídalová M (2018). Muži a ženy pečující o seniory v rodině. Sociologický časopis / Czech Sociological Review 54(2): 219-251. DOI: 10.13060/00380288.2018.54.2.400.

9. Fischer-Rosenthal W, Rosenthal G (2001). Analýza narativně-biografických rozhovorů. Biograf 24: 9-20.

10. Geissler H (2021). Neformální péče v datech. In: Fryč V, Chmelová M, Adámková P (Eds) (2021). Neformální péče v teorii a praxi. Sborník odborných statí. Praha: Pasparta publishing, pp. 56-64.

11. Geissler H, Holeňová A, Horová T, Jirát D, Schlanger J, Solnářová D, et al. (2015a). Výstupní analytická zpráva o současné situaci a potřebách pečujících osob a bariérách pro poskytování neformální péče v ČR. Praha: Fond dalšího vzdělávání.
12. Geissler $\mathrm{H}$, Holeňová $\mathrm{A}$, Horová $\mathrm{T}$, Jirát $\mathrm{D}$, Solnářová $\mathrm{D}$, Svobodová K, et al. (2015b). Neformální péče ve vybraných státech Evropské unie. Komparativní rešerše a identifikace příkladů dobré praxe. Praha: Fond dalšího vzdělávání.

13. Greenwood N, Mackenzie A (2010). Informal caring for stroke survivors: Meta-ethnographic review of qualitative literature. Maturitas 66(3): 268-276. DOI: 10.1016/j. maturitas.2010.03.017.

14. Greenwood N, Mackenzie A, Cloud G, Wilson N (2010). Loss of autonomy, control and independence when caring: A qualitative study of informal carers of stroke survivors in the first three months after discharge. Disabil Rehabil 32(2): 125-133. DOI: 10.3109/09638280903050069.

15. Horová J, Bártlová S, Hajduchová H, Motlová L, Trešlová M, Záškodná H, Brabcová I (2021). Mezinárodní přehled podpory neformálního (rodinného) pečovatelství. Sociální práce / Sociálna práca 21(2): 20-43.

16. Hubíková O (2021). Rozvoj sociální práce zaměřené na neformální pečující. In: Fryč V, Chmelová M, Adámková P (Eds) (2021). Neformální péče v teorii a praxi. Sborník odborných statí. Praha: Pasparta publishing, pp. 84-12.

17. Imarhiagbe FA, Asemota AU, Oripelaye BA, Akpekpe JE, Owolabi AA, Abidakun AO, et al. (2017). Burden of Informal Caregivers of Stroke Survivors: Validation of the Zarit Burden Interview in an African Population. Ann Afr Med 16(2): 46-51. DOI: 10.4103/aam.aam_213_16.

18. Jegermalm M (2006). Informal care in Sweden: a typology of care and caregivers. Int J Soc Welf 15: 332-343. DOI: 10/1111/j.1468-2397.2006.00400.x

19. Jeřábek H (Ed.) (2013). Mezigenerační solidarita v péči o seniory. Praha: Sociologické nakladatelství (SLON).

20. Joo H, Dunet DO, Fang J, Wang G (2014). Cost of informal caregiving associated with stroke among the elderly in the United States. Neurology 83(20): 1831-1837. DOI: 10.1212/ WNL.0000000000000986.

21. Morris SM, Thomas C (2002). The need to know: informal carers and information. Eur J Cancer Care 11(3): 183-187. DOI: 10.1046/j.1365-2354.2002.00337.x.

22. Mosquera I, Vergara I, Larrañaga I, Machón M, del Río M, Calderón C (2015). Measuring the impact of informal elderly caregiving: a systematic review of tools. Qual Life Res 25(5): 1059-1092. DOI: 10.1007/s11136-015-1159-4.

23. Nemčíková M, Katreniaková Z, Dobríková P, Nagyová I (2020). Efektívne intervencie pre znižovanie zátaže neformálnych 
opatrovatel'ov osôb s demenciou pri Alzheimerovej chorobe: systematický prehl'ad. Sociální práce / Sociálna práca 20(6): 120-140.

24. Neubert L, Gottschalk S, König H-H, Brettschneider C (2020). Dementia care-giving from a family network perspective in Germany: A typology. Health Soc Care Comm 00: 1-13. DOI: 10.1111/hsc.13161.

25. Pendergrass A, Beische D, Becker C, Hautzinger M, Pfeiffer K (2015). An abbreviated German version of the Sense of Competence Questionnaire among informal caregivers of relatives who had a stroke: development and validation. Eur J Ageing 12(3): 203-213. DOI: 10.1007/s10433-015-0342-3.

26. Pesantes MA, Brandt LR, Ipince A, Miranda JJ, Diez-Canseco F (2017). An exploration into caring for a stroke-survivor in Lima, Peru: Emotional impact, stress factors, coping mechanisms and unmet needs of informal caregivers. eNeurologicalSci 6: 33-50. DOI: 10.1016/j.ensci.2016.11.004

27. Rosenthal G (2018). Interpretive Social Research, An Introduction. Göttingen: Göttingen University Press.
28. Simon C, Little P, Birtwistle J, Kendrick T (2003). A questionnaire to measure satisfaction with community services for informal carers of stroke patients: construction and initial piloting. Health Soc Care Community 11(2): 129-137. DOI: 10.1046/j.1365-2524.2003.00408.x.

29. Smith LN, Lawrence M, Kerr SM, Langhorne P, Lees KR (2004). Informal carers' experience of caring for stroke survivors. J Adv Nurs 46(3): 235-244. DOI: 10.1111/j.1365-2648.2004.02983.x.

30. Strang S, Fährn J, Strang P, Ronstad A, Danielsson L (2019). Support to informal caregivers of patients with severe chronic obstructive pulmonary disease: a qualitative study of caregivers' and professionals' experiences in Swedish hospitals. BMJ Open 9(8): e028720. DOI: 10.1136/bmjopen-2018-028720.

31. Weber M (2012). Collected methodological writings. London and New York: Routledge.

32. White CL, Lauzon S, Yaffe MJ, Wood-Dauphinee S (2004). Toward a model of quality of life for family caregivers of stroke survivors. Qual Life Res 13(3): 625-638. DOI: 10.1023/B:QURE.0000021312.37592.4f. 